\title{
Dal rilievo al projection mapping. La ricomposizione degli affreschi della chiesa di Santa Caterina Martire in Ferrara
}

\author{
Manuela Incerti \\ Stefano Giannetti \\ Achille Lodovisi \\ Andrea Sardo
}

\section{Abstract}

Nel salone d'onore del Museo di Casa Romei a Ferrara è conservata una Crocifissione di Cristo di autore ignoto datata I $350 \mathrm{ca}$. La scena, fulcro di un complesso programma, fu staccata da una parete della chiesa di Santa Caterina di Ferrara nel 1935. In basso, sul lato sinistro, una lacuna interrompe il racconto di cui si intuisce comunque il senso grazie a parti di vesti riconducibili a figure umane. Questo progetto, attraverso la ricomposizione grafica dell'intero ciclo e una proiezione di luce sul reperto museale sopra citato, vuole risarcire il vuoto esistente e restituire una lettura iconografica e percettiva più esauriente dell'intero racconto.

\section{Parole chiave}

rilievo, Ferrara, fotografia HR, video mapping, dipinto su muro.

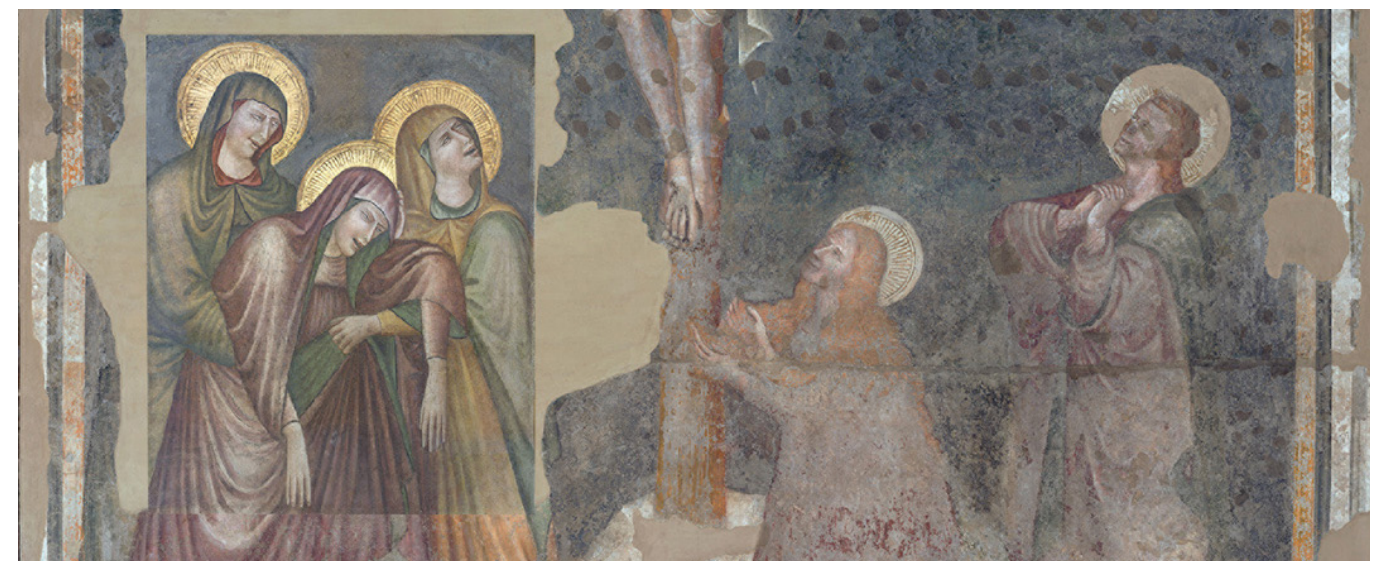




\section{Introduzione}

L'esistenza del monastero femminile di Santa Caterina d'Alessandria al di fuori della cinta muraria della città di Ferrara è testimoniata da un documento del I208. Al I292 risale invece la nuova chiesa ad aula unica che misurava 14,60 × 36,80 m circa ed era divisa in due parti da un tramezzo: il coro delle monache era posto ad est, mentre lo spazio dei fedeli era ad ovest. Durante il secolo XIV su tutte le superfici interne furono realizzati dipinti murali: tra questi emergeva un grande Giudizio Universale, di circa 150 mq, che ricollegandosi agli analoghi esempi di Padova, Pomposa e Rimini caratterizzava la facciata interna di levante. A causa dei progressivi e reiterati distacchi avvenuti nel corso degli ultimi I 50 anni, il quadro d'insieme e l'originaria configurazione della parete sono oggi compromessi impedendo la lettura complessiva del suo contenuto e dei suoi significati.

In casi come questo l'impiego delle nuove tecnologie, sia nelle fasi della ricerca sia nelle fasi di comunicazione, può indubbiamente contribuire alla restituzione di contenuti e conoscenze inedite, non solo agli esperti ma anche al pubblico comune, in una logica di inclusione percettiva, sensoriale e culturale.

Questo lavoro ha come oggetto una prima ipotesi di ricomposizione dell'intera parete e la realizzazione di una proiezione luminosa del frammento pittorico che, distaccato dalla Crocefissione (fig. I), lasciò Ferrara già nei primi anni del Novecento. (M.I., S.G.).

Fig. I. Scandita dall'asse verticale della croce, la composizione ha nella parte superiore il Cristo crocifisso circondato
cristion da due coppie di angel affranti:il sangue che sgorga dalle sue ferite è raccolto in tre alti calici. Un quarto angelo si

straccia le vesti sul petto nella medesima posa utilizzata da Giotto nella cappella degli Scrovegni di Padova (1303-05) e nella Basilica Inferiore di Assisi (foto di Ghigo Roli, Modena).

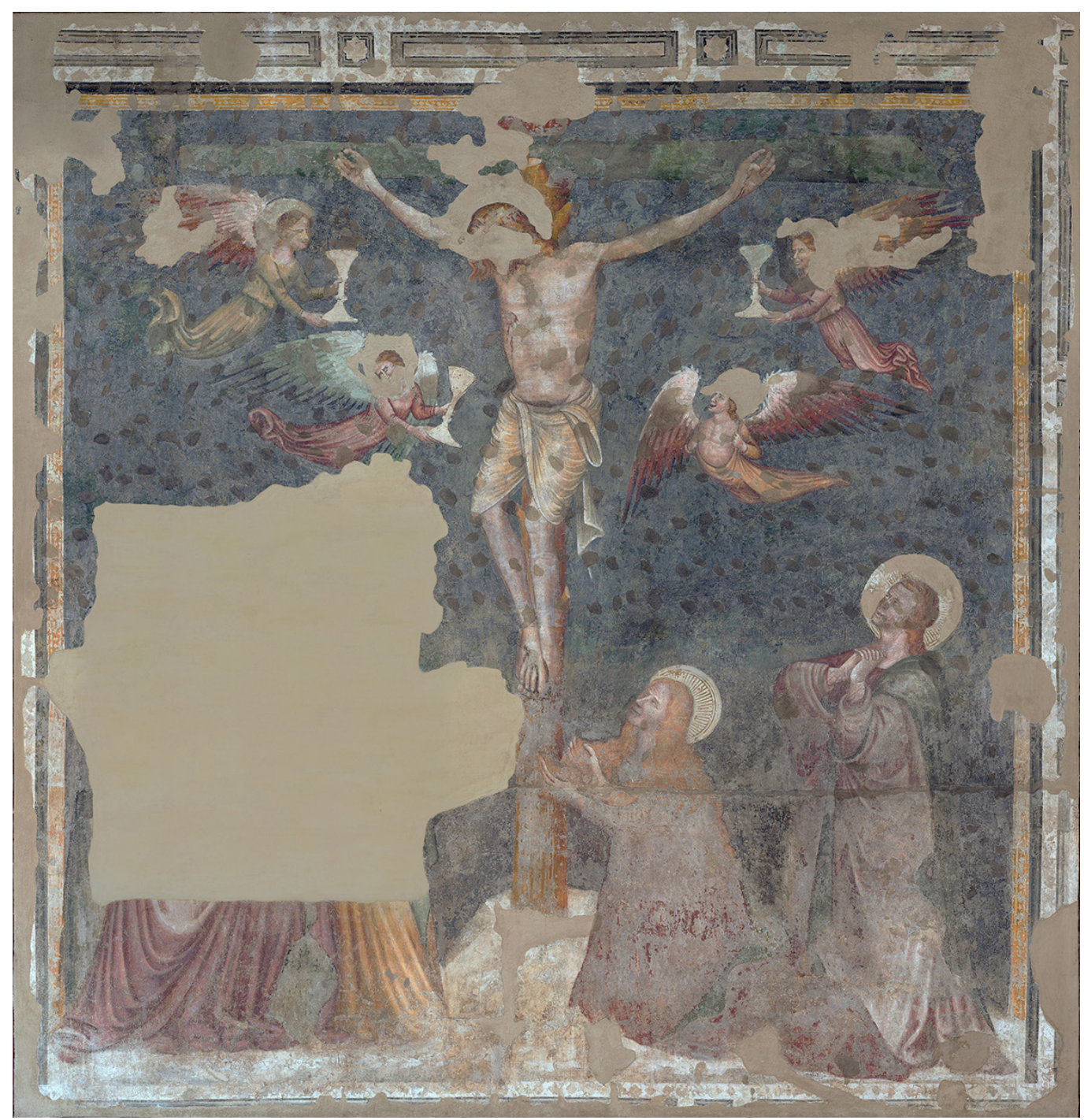




\section{La fase 2 del progetto Sogno o Son Deste a Ferrara}

II progetto Sogno o Son Deste mira a ricostruire i decori parietali di alcune architetture estensi attraverso l'utilizzo di una tecnica chiamata projection mapping. Liniziativa, ideata dalla Fondazione di Vignola e oggi sostenuta anche da altre fondazioni bancarie del territorio, ha raccolto il patrocinio delle amministrazioni comunali coinvolte, del MIBACT, del Polo Museale dell'Emilia-Romagna e dell'Università di Ferrara. Nel 20 I8, sulla base dei pochi lacerti rimasti su alcune porzioni esterne della Rocca di Vignola e del cortile d'onore di Casa Romei di Ferrara, è stato possibile ipotizzare lo sviluppo degli antichi decori e, attraverso il mapping, riproporli nella loro interezza. Le criticità emerse nel corso dell'esperienza appena passata [Giannetti et al. 2019] hanno offerto la base per l'ideazione e lo sviluppo di un workflow più adeguato su due nuovi casi studio: la zona di ingresso della Rocca di Vignola (due pareti e la volta a botte che copre l'androne di ingresso) e l'affresco della Crocifissione esposto nel Museo di casa Romei che presenta un'importante lacuna conservata in altro luogo. (M.I., A.L.).

Fig. 2. Immagine dell'allestimento museale nella seconda metà del novecento. Ai piedi della croce, sulla destra, sono la Maddalena inginocchiata (Maria di Magdala) e «il discepolo che egli amava» (Gv. 19, 26). Sul lato sinistro una grande grande lacuna interrompe il racconto.

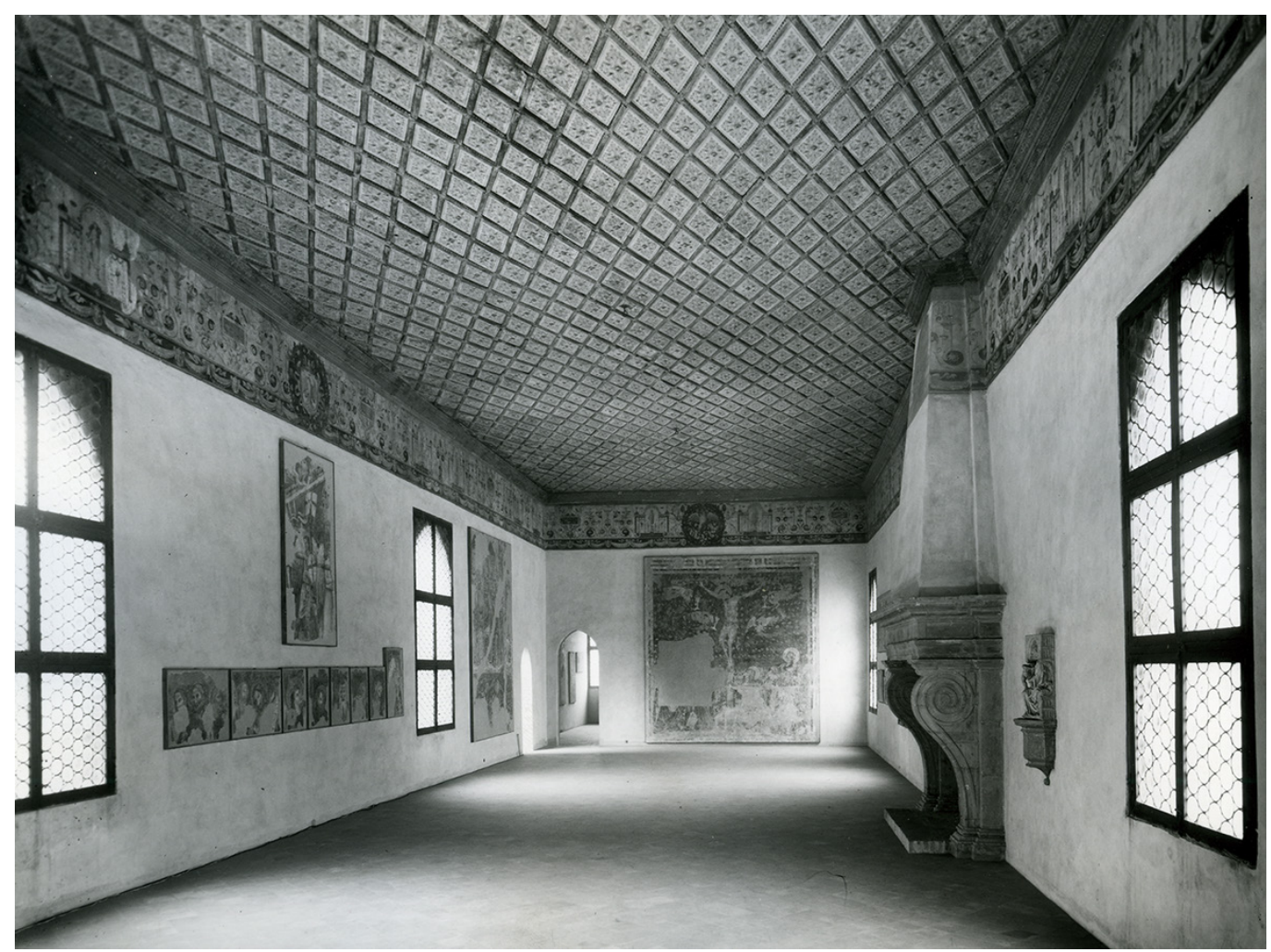

II Museo di Casa Romei e i reperti della Chiesa di Santa Caterina

L'edificazione del primo nucleo della Casa di Giovanni Romei avviene tra il | 443- | 445 e la sua costruzione fu realizzata in diversi momenti, per quanto ravvicinati nel tempo. II risultato di questo processo di costruzione, frantumato nel corso di almeno tre decenni e oggetto di ulteriori modifiche un secolo dopo il suo avvio, è un eccezionale esempio di architettura che costituisce una testimonianza pressoché integra delle diverse tecniche costruttive e del gusto decorativo di un periodo di transizione tra i modi medievali e quelli propri del pieno Rinascimento.

L'edificio fu demanializzato nel I 866 e - a partire dai primi anni del Novecento - la Soprintendenza ai Monumenti di Ravenna ne ha curato la manutenzione e i restauri. Nel 1954 il Soprintendente Arrigo Buonomo, ricorda come Casa Romei "dovrà divenire, come già noto 
Fig. 3. Struttura della parete est (senza spessori mu rari) dedotta dalle misure dei due rilievi documentati del 1868 (rosso) e del 1918 (verde). La forma e le dimensioni in altezza delle finestre originali non è annotata nei rilievi consultati. La facciata misurava 13,45 m di larghezza per una altezza massima di circa $13,75 \mathrm{~m}$. al colmo de circa 13,75 m. al colmo de era di $0.6 \mathrm{~m}$ ( 1.5 piedi era di 0,6 ferraresi)

Fig. 4. Parete interna della chiesa lato est: le aree colorate identificano la posizione dei diversi episodi.

Fig. 5. Ipotesi di ricomposizione della parete sulla base della documentazıone fotografica. II retino blu identifica i reperti esistenti per i quali non esistono dubbi sull'originale posizionamento Con il tratteggio sono indicati il perimegg sono indicati: perimetro co, il profilo delle edicole co, il profilo delle edicole in cul sono posti 12 santi. T'andamento della cornice esterna simile a quella de Giudizio Universale nella chiesa di Sant'Agostino di Rimini.
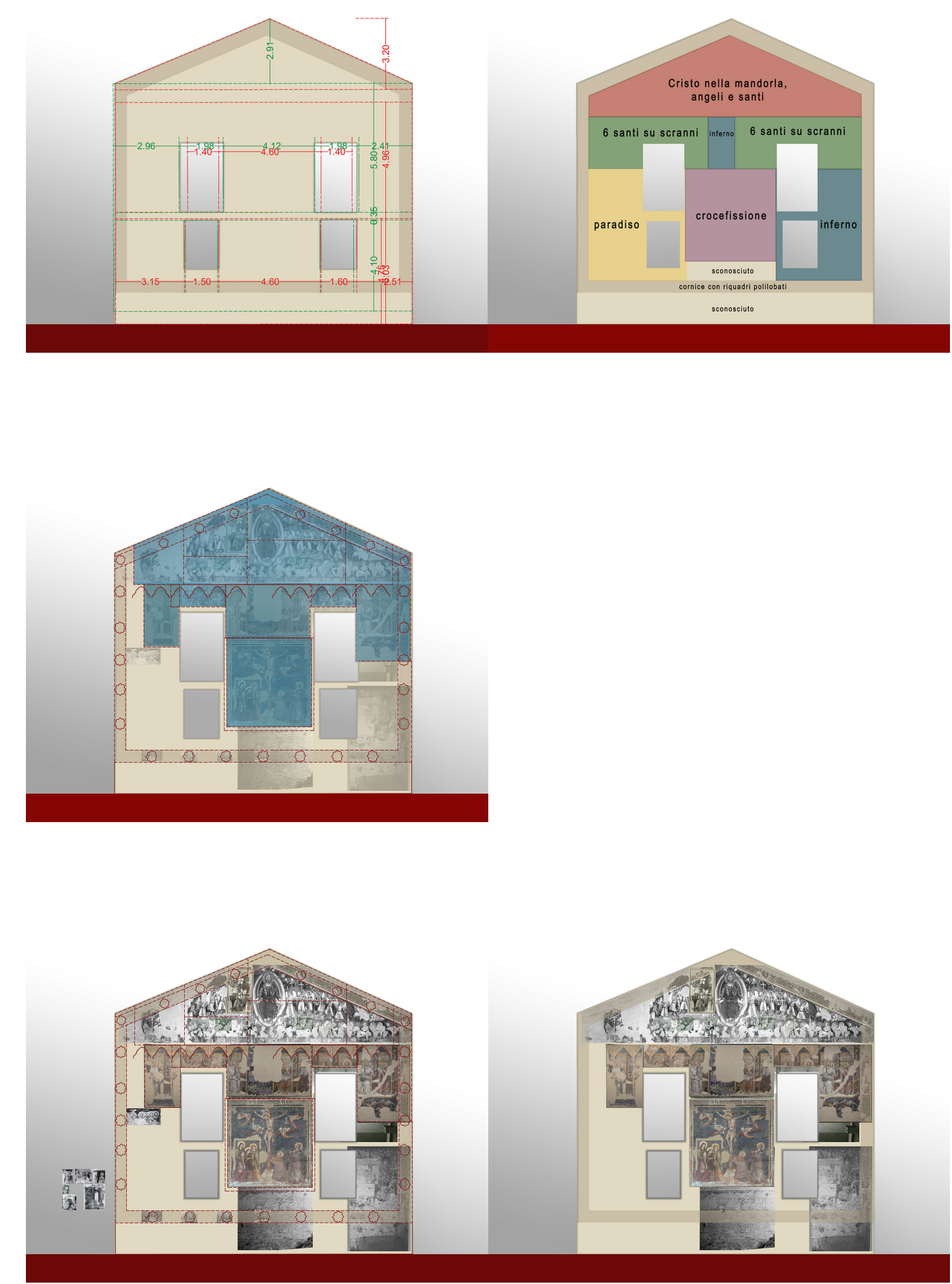

Fig. 6. Ipotesi di ricomposizione della parete: in basso a destra la rappresentazione dell'inferno della quale non esistono informazioni oltre alla fotografia storica. Nella cornice in basso sono stati posizionati alcuni dei riquadri polilobati con figure di monaci e santi. Sul lato sinistro, esternamente al perimetro della parete, sono alcuni dettaglı per I qualı non stata ancora individuata una idonea collocazione.

Fig. 7. Ipotesi di ricomposizione della parete con i soli elementi certi. 
Fig. 8. Elenco de

frammenti documentati da materiale fotografico. La scena dell'inferno, fotografata ancora in situ prima del distacco della Crocefissione, era posizionata nella parete in basso a destra e non risultano testimonianze che ne attestino la rimozione. a codesto Ministero, sede di una raccolta di affreschi appartenenti ad edifici ferraresi, andati distrutti dalla guerra" [Archivio Storico della Soprintendenza B.A.P. di Ravenna, ora SABAP di Bologna, cartella n 1 I5-FE, nota del 25 febbraio 1954]. In quell'anno prende pertanto corpo l'assetto definitivo del museo, pressoché invariato fino alla fine del ventesimo secolo, con un allestimento che alterna frammenti di dipinti murali a sculture e decorazioni.

Nel Salone d'Onore (fig. 2), grazie all'operato di Gualtiero Medri [Medri 1955] e nell'ambito del percorso del nuovo museo statale inaugurato il 5 novembre 1955, sono sistemati i grandi pannelli con alcuni degli affreschi strappati dalla Chiesa di Santa Caterina in via sporadica a partire dal 1904 ed in via più sistematica e consapevole, grazie all'interessamento diretto di Cesare Brandi, nel 1935 [Lamborghini 2008]. (A.S.).

\begin{tabular}{|c|c|c|c|c|c|}
\hline n. & Soggetto & $\begin{array}{l}\text { Numero } \\
\text { pannelli }\end{array}$ & $\begin{array}{l}\text { Posizione } \\
\text { (dall'alto) }\end{array}$ & $\begin{array}{l}\text { Soggetto } \\
\text { conservatore }\end{array}$ & Bibliografia \\
\hline 1 & $\begin{array}{l}\text { Cristo nella mandorla circondato da angeli; in } \\
\text { basso: Maria, San Giovanni Battista e santi }\end{array}$ & 6 & 1 & A & (Bentini 1992, pp. 17-18) \\
\hline 2 & $\begin{array}{l}\text { Figure di } 12 \text { santi seduti su dei seggi. } \\
\text { Al centro la discesa degli angeli verso l'inferno }\end{array}$ & 5 & 2 & B/B1/B2 & (Varese 1976) \\
\hline 3 & Paradiso, santi & 2 & 3 sinistra & D & - \\
\hline 4 & Crocefissione & 1 & 3 centro & B & $\begin{array}{l}\text { (Lamborghini 2008) } \\
\text { (Varese 1976) }\end{array}$ \\
\hline 5 & Tre donne dolenti & 1 & 3 centro & c & $\begin{array}{l}\text { (Lamborghini 2008) } \\
\text { (Varese 1976) }\end{array}$ \\
\hline 6 & Inferno, dannati & - & 3 destra & $\mathrm{F}$ & \\
\hline 7 & $\begin{array}{l}\text { Figure di monaci e sante in quadrati polilobati } \\
\text { ruotati }\end{array}$ & 4 & $\begin{array}{c}\text { fascia } \\
\text { perimetrale }\end{array}$ & B & - \\
\hline 8 & Altre figure & 6 & non nota & AeF & (Mattaliano 1991)- \\
\hline A & Pinacoteca Nazionale Ferrara/restauratore & B & Casa Romei & & \\
\hline B1 & Casa Romei//CR & B2 & Casa Romei/re & auratore & \\
\hline$c$ & Collezione Ricasoli-Firidolfi & D & Fototeca Zeri & & \\
\hline E & Fototeca Musei Civici Ferrara & $\mathrm{F}$ & Sconosciuto & & \\
\hline
\end{tabular}

\section{II rilievo come strumento di ricomposizione degli affreschi}

Dal 20 giugno al 30 settembre del 1935 ebbe luogo a palazzo dell'Arengo di Rimini la mostra La Pittura Riminese del Trecento curata da Cesare Brandi ( 1906- 1988) che per l'occasione editò anche un importante catalogo contenente il repertorio artistico più completo allora disponibile e un ampio numero di immagini fotografiche [Brandi 1935]. Solamente due anni prima, giovanissimo, aveva vinto il concorso come Ispettore nei ruoli dell'Amministrazione delle Antichità e Belle Arti ed era stato trasferito presso la Soprintendenza ai Monumenti di Bologna, sezione medievale. In tale ruolo, e alla luce dei recenti studi condotti sulla pittura riminese, effettuò un sopralluogo nella ex-Chiesa di Santa Caterina stendendo una dettagliata relazione, datata 2 I novembre 1935, dalla quale è possibile dedurre elementi utili alla ricomposizione dell'intero ciclo.

"Nella parete di fondo della sala ultima adibita a Museo di Storia Naturale della Scuola tecnica industriale di Ferrara, si conservano notevoli resti di un grande affresco del Sec. XIV raffigurante il giudizio finale: di tale affresco era fin qui visibile solo la parte cuspidata con la mandorla contenente il Cristo, con le figure della Madonna e di S. Giovanni Battista, e le schiere degli angeli volanti. Più in basso, fra le due finestre rimanevano gli avanzi di una crocifissione che veniva interrotta dall'impiantito e che continuava, mutila e rovinata, nel sottostante magazzino di legnami. Tali avanzi pittorici non sono però i soli visibili nell'edificio poiché la ex-Chiesa di S. Caterina [...] era completamente affrescata [...]. Tutte le pitture furono imbiancate nel Sec. XVII quando ancora la Chiesa era aperta al culto, e solo la Crocifissione venne rispettata [...]. Alla metà del Sec. XIX vennero compiute diverse mutilazioni asportando pezzi dell'affresco della Crocifissione e di diversi altri affioranti dalla scialbatura, poiché nel frattempo la Chiesa era stata chiusa al Culto e divisa in due piani" [Archivio Storico della Soprintendenza B.A.P. di Ravenna, cartella n W3- I 829].

Nella minuziosa relazione Brandi descrive non solo le vicende storiche dei distacchi sottolineando il "barbaro metodo di asportare solo le teste e le figure meglio conservate" ma anche le varie persone coinvolte negli eventi. Scorrendo l'esposizione è possibile individuare le 
Fig. 9. A sinistra: immagine complessiva delle tre donne; a destra: dettaglio in scala $1: \mid$ dell'immagine ad alta risoluzione dello stesso soggetto. Si Ringrazia Giovanni RicaRingrazia Giovanni Ricasoli Firidolfi per la gentil concessione accordata.

Fig. 10. A sinistra: immagine originale del vetrino prova: l'immagine delle "tre donne" è stata suddivisa in quattro different porzioni in cui sono stat testati quattro differen bilanciamenti colore e quattro differenti modi di trattare il confine della proiezione.

A destra: una prima prova di proiezione realizzata con proiettore digitale, finalizzata alla verifica geometrica dei confini.
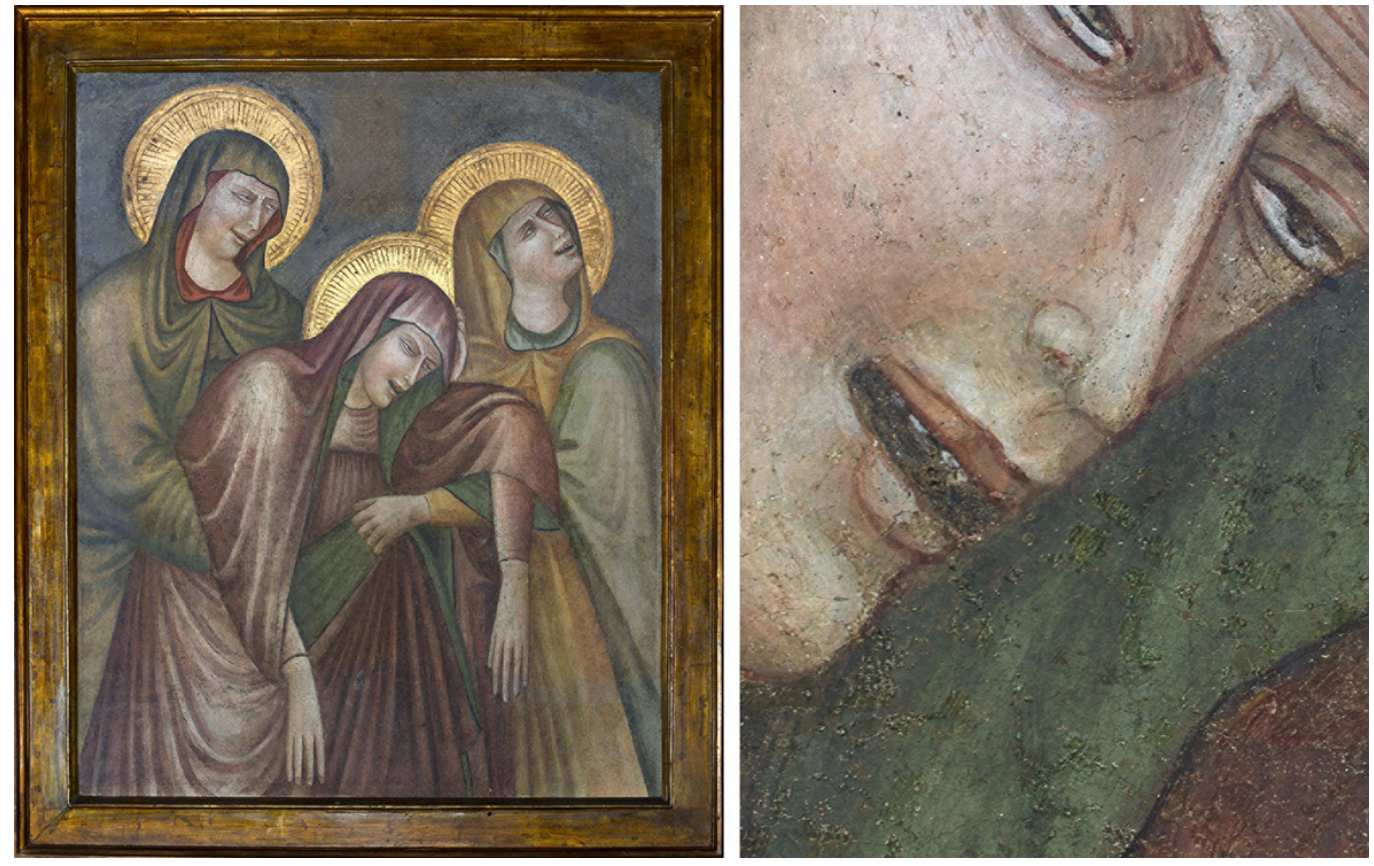

varie scene allora presenti: la parte cuspidata già citata, le figure di santi "seduti in seggi con baldacchini a lobature gotiche" e, poi, "una parte dei Beati, dei Risorti, e dei dannati” oltre alla Crocifissione da cui era stato asportato il riquadro contenente tre donne dolenti. Tale frammento, già appartenente alla Collezione Massari, al momento della stesura del documento, risulta di proprietà della Baronessa Massari Ricasoli e conservato presso la Villa di Voghenza. Nonostante le scalpellature fatte sull'affresco per fare aderire il nuovo intonaco, "le sciupature non sono di tale entità da togliere l'effetto generale di tutta la composizione, che riallacciandosi agli esempi di Padova, di Pomposa e di Rimini, costituisce un documento iconografico di notevole valore. È importante soprattutto la concomitanza di elementi padovani (Giotto e Guariento) e di elementi riminesi" [Archivio Storico della Soprintendenza B.A.P. di Ravenna, cartella n W3- 1829].

Le soppressioni napoleoniche (1798), gli innumerevoli successivi passaggi di proprietà e cambiamenti di destinazioni d'uso, gli eventi bellici (1944), le difficoltà di gestione del patrimonio artistico da parte dell'Amministrazione Comunale nel dopo guerra (Bentini 1992),

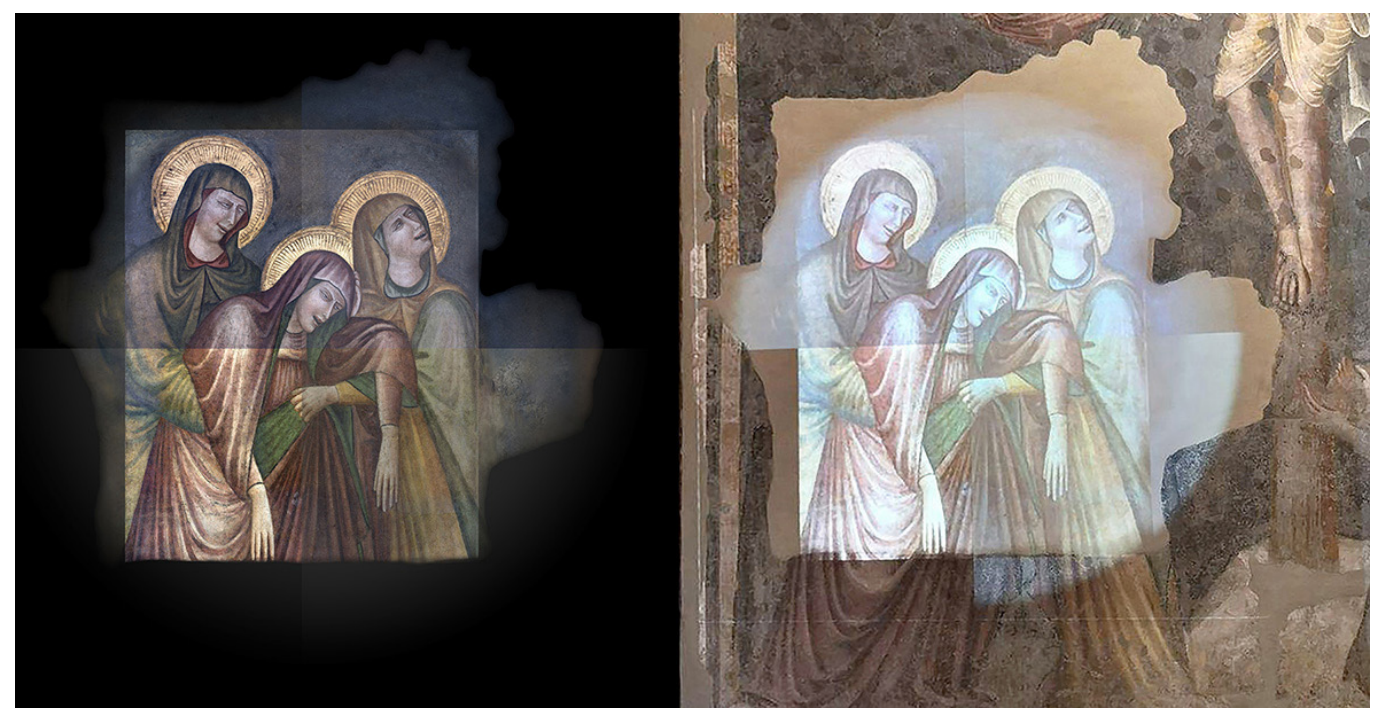


Fig. I I. Frame del video esplicativo realizzato dagli autori in occasione del progetto di valorizzazione della Crocifissione disponibile su totem Casa Romei. hanno inevitabilmente portato alla dispersione del frammenti strappati e, di conseguenza, alla perdita della visione d'insieme.

Nelle figure 3-7 si propone una prima ipotesi ricompositiva dell'intera parete est della chiesa realizzata grazie alle informazioni contenute nei documenti grafici e fotografici consultati. Si tratta dei rilievi realizzati per la perizia comunale del 1868 [Archivio Storico Comunale di Ferrara, Secolo XIX, Istruzione Pubblica, busta 76, fascicolo ${ }^{\circ}$ I] e di quelli realizzati nel I9I 8 dalla Ferrariae Decus [Mattaliano 199/]. La documentazione fotografica, conservata presso la fototeca di Palazzo Bonacossi (Ferrara), l'Archivio fotografico del Polo Museale dell'Emilia Romagna (Bologna) e la Collezione Zeri (Bologna), conta svariate immagini collegabili a più di 25 soggetti diversi, e ci consente di dedurre non solo la sagoma dei frammenti distaccati, ma anche le successive partizioni decise evidentemente per ragioni espositive (fig. 8). (M.I.).

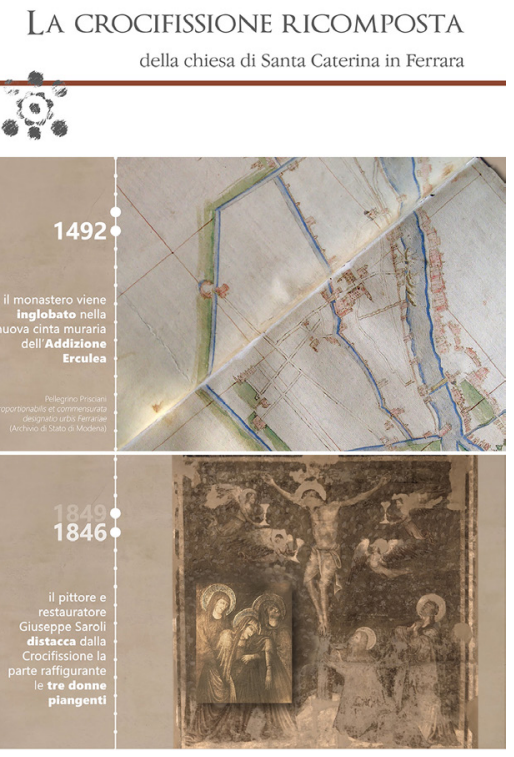

\section{Dall'analisi del colore alla proiezione di luce}

La ricomposizione dell'affresco della crocifissione è avvenuta proiettando la porzione distaccata delle tre donne, conservata a Firenze, all'interno della lacuna dell'affresco conservato a casa Romei a Ferrara.

La programmazione del mapping, (la selezione degli strumenti e dei metodi) come accennato nei paragrafi precedenti, si basa sull'esperienza maturata all'interno del progetto Sogno o son Deste [Giannetti et al. 2019]. Nel caso studio in oggetto, tuttavia, è stato necessario elaborare un workflow specifico.

Le problematiche affrontate sono state di due tipi:

Problematiche peculiari.

I) L'oggetto della proiezione non è una ricostruzione filologica, ma l'immagine di un affresco esistente.

2) II colore dello sfondo della proiezione (ovvero il colore dell'intonaco della crocifissione in corrispondenza della lacuna) non è neutro e incide in modo non trascurabile sul colore della proiezione.

3) Analisi delle cromie e simulazione dell'effetto finale

Problematiche generali.

4) Come osservato nei precedenti casi studio, la realizzazione del vetrino da proiettare non permette una gestione del colore accurata [Giannetti et al. 2019]; inoltre la temperatura della lampada del proiettore incide sulla tinta finale. 
La prima problematica affrontata ha riguardato l'integrazione dell'affresco. Questa è stata interamente condotta attraverso riprese fotografiche. Nel dettaglio, sono state acquisiti, sia l'affresco della crocifissione, che il lacerto conservato a Firenze. Poiché i due oggetti, restaurati con approcci molto diversi, sono conservati in luoghi diversi in condizioni di luminosità ambientale differenti, per attivare un confronto è stato necessario improntare un processo di profilazione del colore. Questo è stato svolto con l'ausilio del Color Checker della X-Rite. Prima, è stata realizzata una campagna fotografica ad alta risoluzione dell'affresco raffigurante le 'tre donne' (fig. 9).

Successivamente è stata condotta l'acquisizione fotografica della Crocifissione conservata a Ferrara. In questo caso, poiché l'affresco non era oggetto della proiezione, ma solamente supporto della stessa, non si è reso necessario utilizzare il materiale della campagna ad alta risoluzione (fig. I), ma è stato sufficiente avere la sola fotografia della lacuna (profilata con l'ausilio del Color Checker e realizzata con la stessa fotocamera e ottica del lacerto fiorentino) per attivare, così, un confronto cromatico delle parti dipinte prossime alla lacuna, e acquisire il colore di sfondo della proiezione (l'intonaco della lacuna è caratterizzato da una tinta tendente al beige).

Una volta corrette le immagini, applicando il profilo colore estratto mediante l'utilizzo del Color Checker, si è potuto attivare un confronto tra le cromie dei due affreschi e modificare il bilanciamento del colore della porzione da proiettare al fine di rendere omogenei i colori nel risultato finale. Per farlo, è stato necessario correggere il colore simulando, contemporaneamente, l'effetto della proiezione, in particolare la fusione dei colori mediante sintesi sottrattiva: il nero, pertanto, si può solo ottenere attraverso la 'non-proiezione' di luce in un ambiente totalmente buio. Per la simulazione si è scelto di procedere mediante l'ausilio dei metodi di fusione in Photoshop: in particolare dei metodi Scolora e Luce intensa.

Al netto della simulazione va tenuto conto che nella percezione globale del colore incide anche l'illuminazione globale dell'ambiente, che, se esterna, è variabile nel tempo. Nella collocazione attuale la Crocifissione di Casa Romei è illuminata da alcune finestre sul lato destro e da una porta sul lato sinistro.

Come descritto nei precedenti studi, anche per questo mapping, si è optato per l'utilizzo di proiettori analogici goled che, nella gestione del colore della proiezione, aggiungono le variabili dettate dalla fase di 'ablazione laser' dei vetrini e dalla temperatura della lampada a led (nominalmente di 4000k); pertanto, la verifica della resa cromatica effettiva è potuta avvenire solo a posteriori, con la proiezione di alcuni vetrini di prova. Durante la proiezione test sono state realizzate altre riprese fotografiche finalizzate al confronto con il file digitale originale del vetrino test. (S.G.).

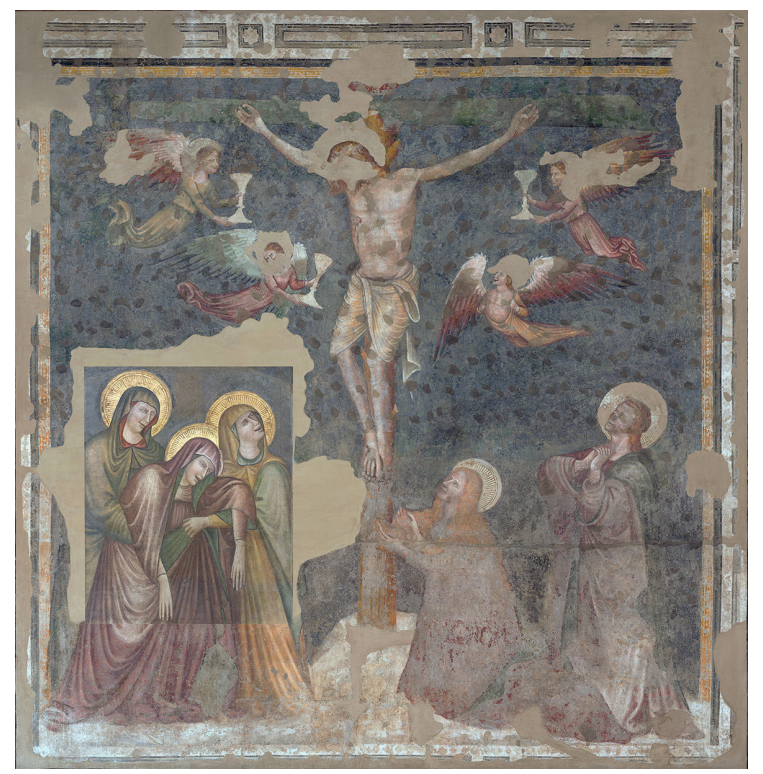




\section{Conclusioni}

Attraverso il workflow descritto, oramai assimilabile ad un progetto di light-design, come nei precedenti casi studio, è stato possibile ricomporre un'opera d'arte pittorica per mostrarla nella sua interezza. Questa finalità è stata perseguita mediante l'affinamento delle tecniche di acquisizione del dato, di elaborazione e di proiezione dello stesso. Infine la valorizzazione del bene è stata arricchita grazie alla realizzazione di un video di 5.30 minuti (fig. II) esplicativo della storia della Crocifissione, dalla fondazione della chiesa che la ospitava sino al progetto di ricomposizione qui presentato (fig. I2). (M.I., S.G.).

\section{Note}

[I] Quest'ultima parte del progetto è stato realizzata grazie al supporto di BPER banca.

[2] Campagna eseguita con fotocamera Canon I00D con ottica Canon 70-200 mm f4 (serie L), impostata a $200 \mathrm{~mm}$. Per coprire l'intera superficie dell'affresco (di dimensioni reali pari a $130 \mathrm{~cm}$ per $104 \mathrm{~cm}$ ) sono stati necessari 86 scatti, realizzati ruotando la macchina intorno al punto nodale dell'ottica attraverso l'ausilio di una testa motorizzata, con un overlap del 20\%. Le immagini sono state sottoposte a processo di stiching all'interno del software Kolor Autopano Giga; l'immagine finale è risultata di dimensioni pari a 21091 per 25342 pixel, che coincidono a 214 per $178 \mathrm{~cm}$ a $300 \mathrm{dpi}$ (ovvero ad una scala maggiore di $1: 1)$.

[3] II metodo Scolora viene definito così da Adobe: "Esamina le informazioni cromatiche in ciascun canale e moltiplica l'inverso del colore applicato e del colore di base. II colore risultante è sempre più chiaro. Scolorando con il nero, il colore resta invariato. Scolorando con il bianco, si ottiene il bianco. L'effetto è simile a quello ottenuto proiettando più diapositive l'una sull'altra". II metodo Luce Intensa viene definito così da Adobe: "Moltiplica o scolora i colori, a seconda del colore applicato. L'effetto è simile a quello ottenuto illuminando l'immagine con un faretto intenso. Se il colore applicato (sorgente luminosa) è più chiaro del grigio al 50\%, l'immagine viene schiarita come se fosse scolorata. Ciò è utile per aggiungere zone di luce all'immagine. Se il colore applicato è più scuro del grigio al 50\%, l'immagine viene scurita come se fosse moltiplicata. Ciò è utile per aggiungere le ombre all'immagine. L'uso del nero o del bianco puro produce il nero o il bianco puro".

\section{Riferimenti bibliografici}

Bentini Jadranka (1992). Pinacoteca Nazionale di Ferrara. Catalogo generale. Introduzione di Andrea Emiliani - Consulenza scientifica di Federico Zeri. Bologna: Nuova Alfa.

Brandi Cesare (1935). Mostra della pittura riminese del Trecento: Rimini, 20 giugno-30 settembre 1935. Rimini:Tip. Garattoni.

Giannetti Stefano, Lodovisi Achille, Sardo Andrea, Grassivaro Marco, Incerti Manuela (2019). Esperienze di projection mapping per la valorizzazione delle facciate dipinte nei territori estensi. Experiences in projection mapping. Enhancing the painted facades of the Estes. In Paolo Belardi (a cura di). Riflessioni: l'arte del disegno/il disegno dell'arte/Reflections: the art of drawing/the drawing of art. Atti del $39^{\circ}$ Convegno dei Docenti delle Discipline della Rappresentazione. Perugia 19-21 settembre 20 I9, pp. 1621-1628. Roma: Gangemi.

Lamborghini Giovanni, (2008). II tassello mancante nella Crocifissione di Santa Caterina Martire. In Voci di una città, 28, pp. I5- I7.

Mattaliano Emanuele (199I). Un affresco restaurato dalla ex chiesa di s. Caterina martire. In Ferrariae Decus, pp. I I 3.

Varese Ranieri (1976). Trecento ferrarese. Ferrara: Cassa di Risparmio di Ferrara.

\section{Sitografia}

<https://helpx.adobe.com/it/photoshop/using/blending-modes.html> Adobe. Guida Utente Photoshop, Metodi di Fusione.

$<$ https://www.sognoosondeste.it/>.

\section{Autori}

Manuela Incerti, Università di Ferrara icm@unife.it

Stefano Giannetti, Università di Ferrara, stefano.giannetti@unife.it

Achille Lodovisi, Fondazione Rocca di Vignola, centrodidocumentazione@fondazionedivignola.it

Andrea Sardo, Direttore Museo di Casa Romei, Ferrara, andreaquintino.sardo@beniculturali.it

Per citare questo capitolo: Incerti Manuela, Giannetti Stefano, Lodovisi Achille, Sardo Andrea (2020). Dal rilievo al projection mapping. La ricomposizione degli affreschi della chiesa di Santa Caterina Martire in Ferrara/From the Survey to Projection Mapping. The Recomposition of the Frescoes of the Church of Santa Caterina Martire in Ferrara. In Arena A., Arena M., Brandolino R.G., Colistra D., Ginex G., Mediati D., Nucifora S., Raffa P. (a cura di). Connettere. Un disegno per annodare e tessere. Atti del $42^{\circ}$ Convegno Internazionale dei Docenti delle Discipline della Rappresentazione/Connecting. Drawing for weaving relationships. Proceedings of the 42th International Conference of Representation Disciplines Teachers. Milano: FrancoAngeli, pp. 3365-3382. 


\title{
From the Survey to Projection Mapping. The Recomposition of the Frescoes of the Church of Santa Caterina Martire in Ferrara
}

\author{
Manuela Incerti \\ Stefano Giannetti \\ Achille Lodovisi \\ Andrea Sardo
}

Abstract

In the hall of honor of the Museum of Casa Romei in Ferrara there is a Crucifixion of Christ by an unknown author dated $1350 \mathrm{ca}$. This scene, the fulcrum of a complex program, was detached from a wall of the church of Santa Caterina di Ferrara in 1935. At the bottom, on the left side, a gap interrupts the story, the meaning of which is however sensed through parts of clothes attributable to human figures. This project, through the graphic recomposition of the entire cycle and a projection of light on the gaps mentioned above, seeks to compensate for the existing void and return a more comprehensive iconographic and perceptual reading of the whole story.

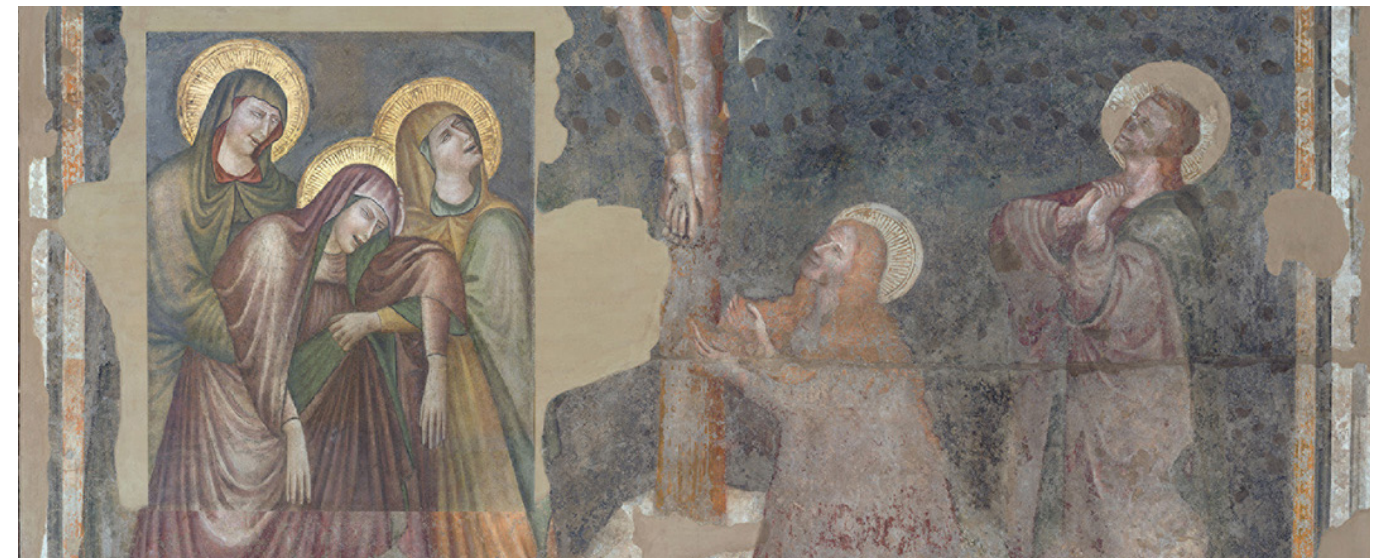




\section{Introduction}

The existence of the female monastery of Santa Caterina d'Alessandria outside the walls of the city of Ferrara is evidenced by a document dated 1208. The new single-space church, measuring | $4.60 \times 36.80 \mathrm{~m}$, dates back to 1292 . It was divided into two parts by a partition: the choir of nuns was placed east, while the space of the faithful was in the west. During the XIVth century, mural paintings covered all the internal surfaces. Among these, a large Universal Judgment characterized the internal facade of the east, covering about I 50 square meters, similar to the analogous examples of Padua, Pomposa and Rimini. Due to the progressive and repeated detachments that have occurred over the past I 50 years, the overall picture and the original configuration of the wall are now compromised, preventing the overall reading of its content and meanings.

In such cases, the use of new technologies, both in research and in communication, can undoubtedly contribute to the restitution of unpublished contents and knowledge, not only to experts but also to the common public, in a logic of perceptive, sensory and cultural inclusion.

The objective of this work has a first hypothesis of recomposition of the entire wall and the realization of a luminous projection of the pictorial fragment that, detached from the Crucifixion (fig. I), left Ferrara in the early twentieth century. (M.I., S.G.).

Fig. I. Marked by the vertical axis of the cross, the upper part of the composition shows the crucified Christ surrounded by two pairs of distraught angels: the blood that flows from $h$ wounds is collected in three tall glasses. A fourth angel tears at his clothes on his chest in the same pose used by Giotto in the Scrovegni Chapel in Padua (1303-05) and in the Lower Basilica of Assisi (photo by Ghiro Roli, Modena).

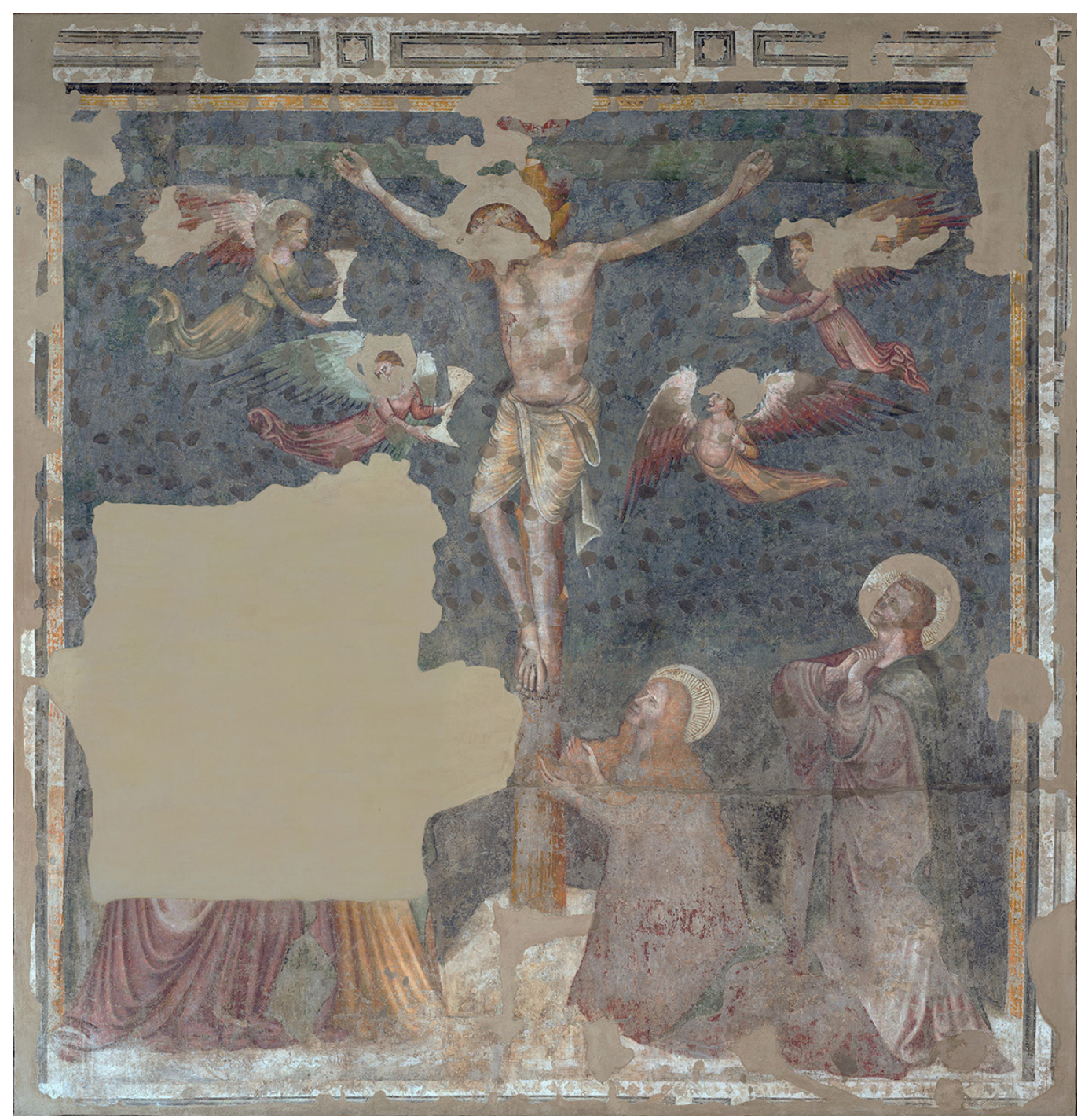




\section{Phase 2 of the project Sogno o Son Deste in Ferrara}

The Sogno o Son Deste project aims to reconstruct the wall decorations of some extensive architectures through the use of a technique called projection mapping. The initiative, conceived by the Vignola Foundation and today also supported by other banking foundations in the area, has gathered the patronage of the municipal administrations involved, MIBACT, the Polo Museale of Emilia-Romagna and the University of Ferrara. In 20 I , on the basis of the few fragments left on some external portions of the Rocca diVignola and the courtyard of honor of Casa Romei in Ferrara, it was possible to hypothesize the development of the ancient decorations and, through mapping, re-propose them in their entirety. The critical issues that emerged during the experience [Giannetti et al. 2019] offered the basis for the conception and development of a more adequate workflow on two new case studies: the entrance area of the Rocca di Vignola (two walls and the barrel vault that covers the entrance hall) and the fresco of the Crucifixion exhibited in the Museum of Casa Romei, which has an important part missing that is preserved elsewhere. (M.I., A.L.).

Fig. 2. Image of the second haf of the ieth century At the foot eth century. At the foo of the cross, on the right, are the kneeling Magdalene (Mary of Magdala) and "the disciple whom he loved" (Gv 19,26). On the left side a large gap interrupts the story

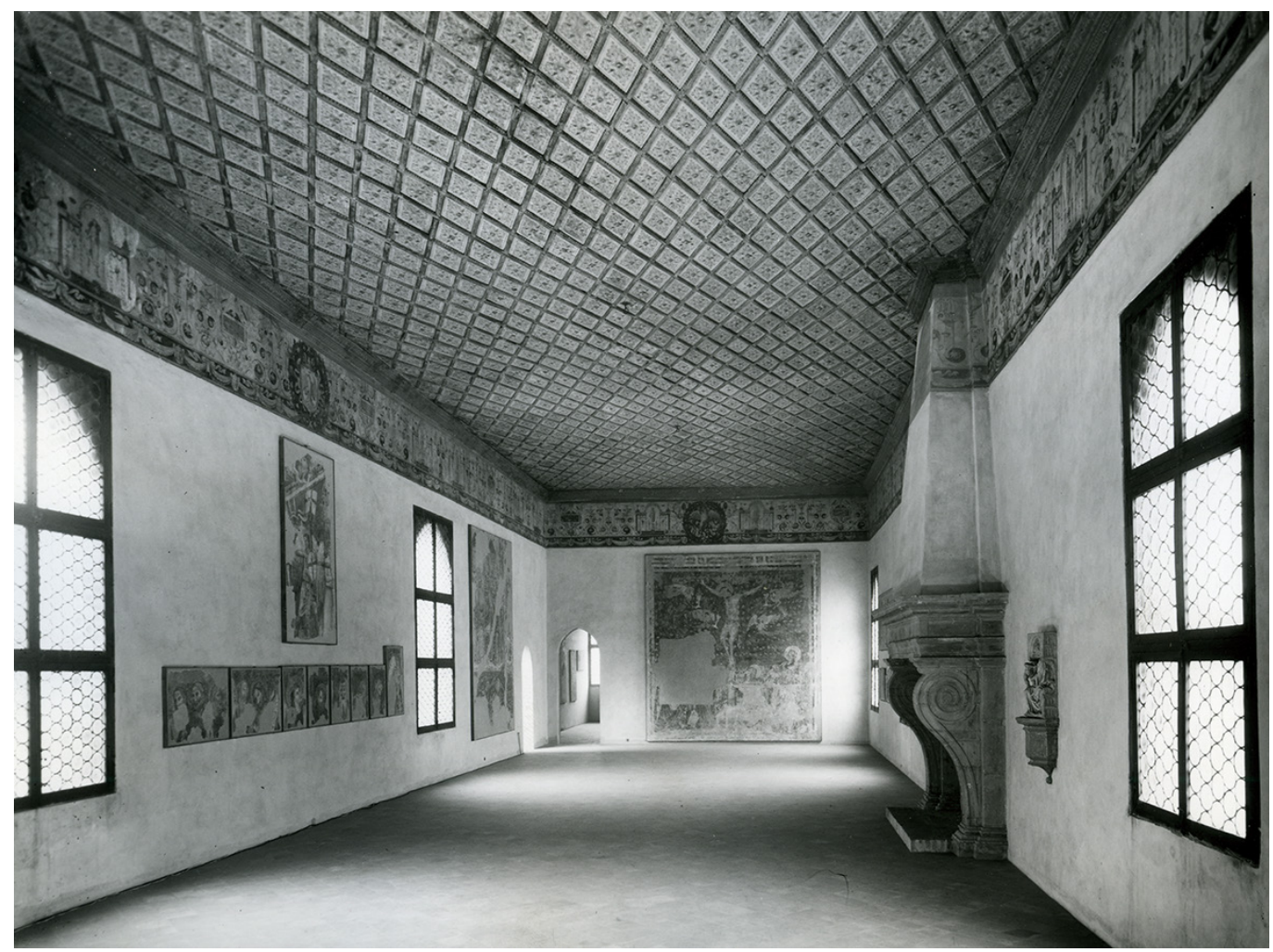

The Museum of Casa Romei and the frescoes of the Church of Santa Caterina

The construction of the house of Giovanni Romei began in I 443- I 445 and was completed in a few years. The result of this building process, throughout at least three decades and with further modifications a century later, is an exceptional piece of architecture bearing witness with its intact structures, of different construction techniques and the taste for decoration of a transition period between medieval and renaissance styles.

The building was acquired by the Italian State in 1866 and - starting from the first years of XX century - the Soprintendenza ai Monumenti di Ravenna, carried out conservation and maintenance works. In 1954 the Superintendent Arrigo Buonomo wrote that "Casa 
Fig. 3. Structure of the east wall (without wall thicknesses) deduced from the measurements of the two surveys documented in 1868 (red) and 1918 (green). The shape and height dimensions of the original windows are not noted in the consulted surveys The facade measured $13.45 \mathrm{~m}$ in width with a maximum height wh a maximum height of approximately $13.75 \mathrm{~m}$ at the top of the roof and (1.5 Ferrarese feet). ( 1.5 Ferrarese feet).

Fig. 4. Internal wall of the church, east side: the coloured areas identify the position of various episodes.
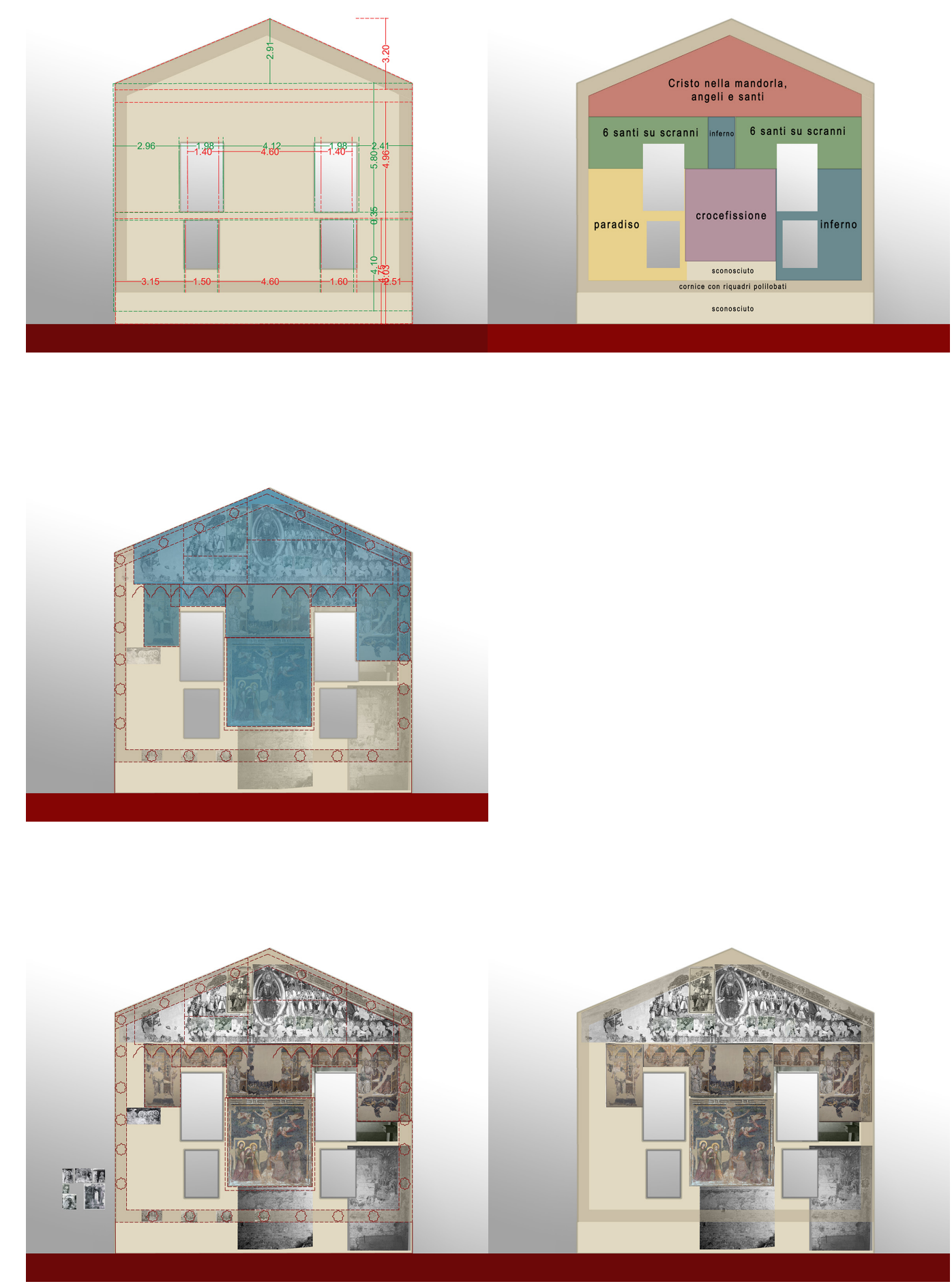

Fig. 5. Hypothesis of recomposition of the wall based on photographic documentation. The blue net identifies the existing finds, whose original

positioning is known. The dotted line indicates the perimeter of the panels after detachment, the profile of the stands where the 12 saints are placed and the trend of the external frame similar to that of the Last Judgment in the church of Sant'Agostino in Rimini.

Fig. 6. Hypothesis of recomposition of the wall: on the bottom right is the representation of hell, of which there is no information other than historical photography. Some of the polylobed panels with figures of monks and saints have been placed in the lower frame. On the left side, outside the perimete of the wall, are some details for which a suitable location has not yet been identified.

Fig. 7. Hypothesis of recomposition of the wall with only confirmed elements. 
Romei will host, as the Ministry himself is aware, a collection of frescoes coming from war destroyed buildings of Ferrara" [Archivio Storico della Soprintendenza B.A.P. di Ravenna, SABAP di Bologna, cartella nI5-FE, nota del 25 febbraio 1954]. The final display of the museum, almost unchanged until the end of the $X X$ century, was fixed in that same year, featuring an exhibition of wall paintings, sculptures and pieces of decoration.

In the main hall (fig.2), thanks to the activities of Gualtiero Medri [Medri 1955] and as part of the initiative of the new National museum opened the 5 th November 1955, frescoes form the church of Santa Caterina were set up. These paintings have been detached at irregular intervals, starting from 1904 and - thanks to the work of Cesare Brandi - in a more systematic and diligent way from 1935 [Lamborghini 2008]. (A.S.).

\begin{tabular}{|c|c|c|c|c|c|}
\hline n. & Soggetto & $\begin{array}{l}\text { Numero } \\
\text { pannelli }\end{array}$ & $\begin{array}{l}\text { Posizione } \\
\text { (dall'alto) }\end{array}$ & $\begin{array}{c}\text { Soggetto } \\
\text { conservatore }\end{array}$ & Bibliografia \\
\hline 1 & $\begin{array}{l}\text { Cristo nella mandorla circondato da angeli; in } \\
\text { basso: Maria, San Giovanni Battista e santi }\end{array}$ & 6 & 1 & A & (Bentini 1992, pp. 17-18) \\
\hline 2 & $\begin{array}{l}\text { Figure di } 12 \text { santi seduti su dei seggi. } \\
\text { Al centro la discesa degli angeli verso l'inferno }\end{array}$ & 5 & 2 & B/B1/B2 & (Varese 1976) \\
\hline 3 & Paradiso, santi & 2 & 3 sinistra & D & - \\
\hline 4 & Crocefissione & 1 & 3 centro & B & $\begin{array}{l}\text { (Lamborghini 2008) } \\
\text { (Varese 1976) }\end{array}$ \\
\hline 5 & Tre donne dolenti & 1 & 3 centro & c & $\begin{array}{l}\text { (Lamborghini 2008) } \\
\text { (Varese 1976) }\end{array}$ \\
\hline 6 & Inferno, dannati & & 3 destra & $\mathrm{F}$ & \\
\hline 7 & $\begin{array}{l}\text { Figure di monaci e sante in quadrati polilobati } \\
\text { ruotati }\end{array}$ & 4 & $\begin{array}{c}\text { fascia } \\
\text { perimetrale }\end{array}$ & B & \\
\hline 8 & Altre figure & 6 & non nota & AeF & (Mattaliano 1991)- \\
\hline A & Pinacoteca Nazionale Ferrara/restauratore & B & Casa Romei & & \\
\hline B1 & Casa Romei/lCR & B2 & Casa Romei/re & auratore & \\
\hline c & Collezione Ricasoli-Firidolfi & D & Fototeca Zeri & & \\
\hline E & Fototeca Musei Civici Ferrara & $\mathrm{F}$ & Sconosciuto & & \\
\hline
\end{tabular}

\section{The survey as a tool for recomposing frescoes}

From June 20 to September 30 1935, the exhibition Painting in Rimini in the fourteenth century took place at Palazzo dell'Arengo in Rimini, curated by Cesare Brandi (1906-1988). For the occasion, he also edited a catalogue containing the most important and complete artistic repertoire of the time, with a large number of photographic images [Brandi 1935]. Only two years earlier he had qualified as Inspector for the Administration of Antichità e Belle Arti and had been transferred to the Superintendence of Monuments of Bologna in the medieval section. In this role, and in light of recent studies conducted on Rimini paintings, he carried out an inspection of the ex-Church of Santa Caterina, drawing up a detailed report, dated 2 I November 1935, from which it is possible to deduce useful elements for the recomposition of the entire cycle.

"On the back wall of the last room, used as a Museo di Storia Naturale della Scuola tecnica industriale of Ferrara, there are significant remains of a large fresco of the XIVth century depicting the final judgment. Of this fresco, only the cuspidated part with the almond containing the figures of Christ, the Madonna, St. John the Baptist and the hosts of flying angels was visible. Further down, between the two windows, there were the remains of a crucifixion interrupted by the flooring, which continued, mutilated and ruined, in the underlying wood warehouse.

However, these pictorial remains are not the only ones visible in the building since the ex-Church of S. Caterina [...] was completely frescoed [...]. All the paintings were whitewashed in the XVII century, when the Church was still open to worship, and only the Crucifixion was respected [...]. In the mid-19th century, several mutilations were carried out by removing pieces of the fresco of the Crucifixion and several others emerging from the layer of plaster, since in the meantime the Church had been closed to worship and divided into two floors" [Historical Archive of the Superintendence of the B.A.P. of Ravenna, $n^{\circ} \mathrm{W} 3-$ | 829]. 
Fig. 9. Left: full image of the three women; right: detail in $1: 1$ scale from the high-resolution image of the same subject. We are grateful to Giovanni Ricasoli Firidolfi for granting us permission.

Fig. 10. Left:The original test slide image: the image of the "three women" was divided into four different sections, on which four different colour balance settings and four different ways of dealing with the edge of the projection were tested. Right: an initial test projection carried out with a digital projector to check the shape of the edges.
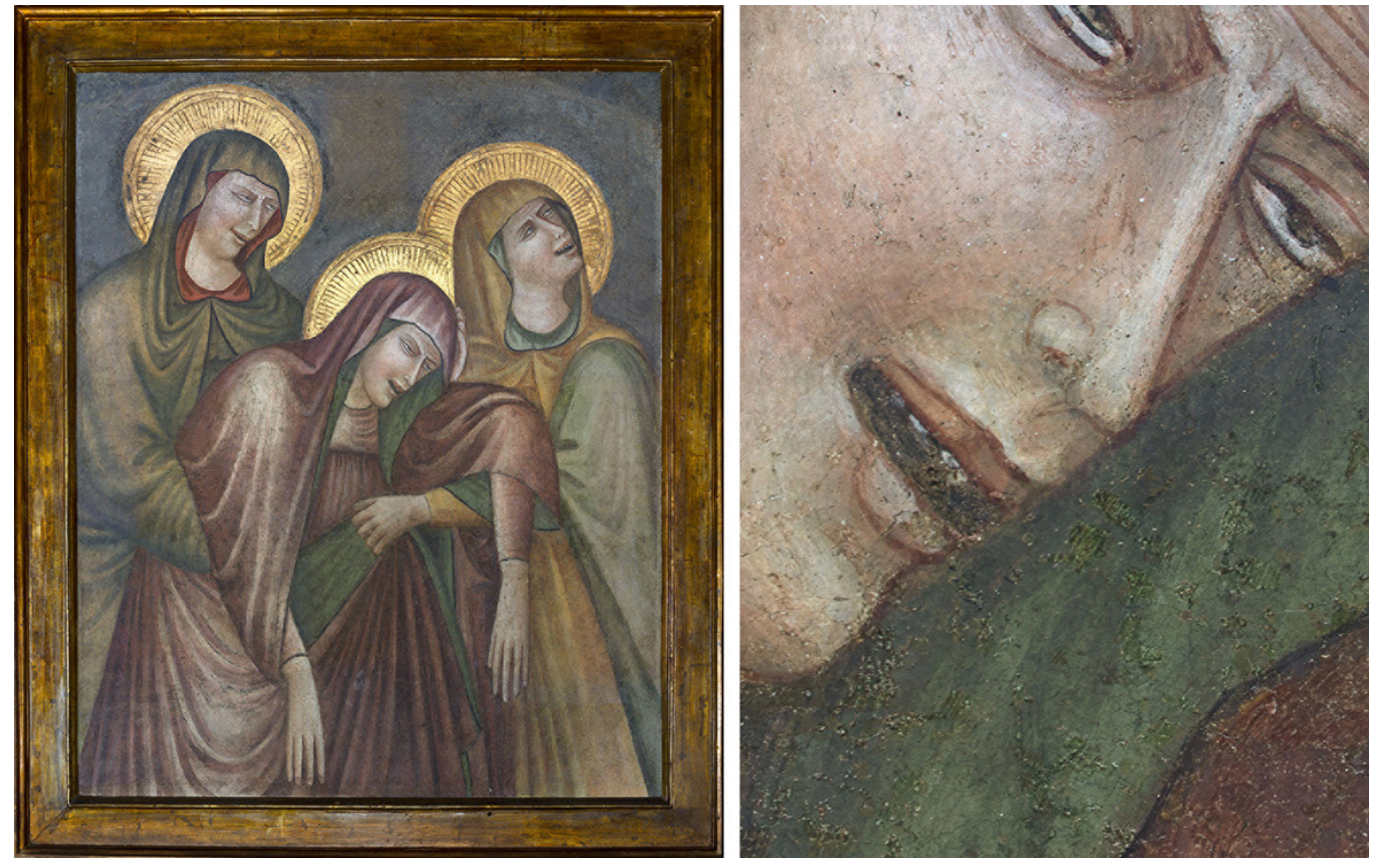

In the meticulous report, Brandi not only describes the historical events of the detachments, underlining the "barbaric method of removing only the best preserved heads and figures", but also the various people involved in the events. By running through the account, it is possible to identify the various scenes that were then present: the previously mentioned cuspidated part, the figures of saints "seated in seats with gothic lobed canopies" and "a part of the Blessed, the Risen, and the damned" in addition to the Crucifixion from which the box containing three mourning women had been removed. This fragment, already belonging to the Massari Collection at the time of writing, is owned by Baroness Massari Ricasoli and kept in the Villa di Voghenza.

Despite the chippings made on the fresco to make the new plaster adhere, "the damage is not of such magnitude as to remove the general effect of the whole composition, which, following the examples of Padua, Pomposa and Rimini, constitutes an iconographic document of considerable value. Above all, the combination of Paduan elements (Giotto and Guariento) and elements from Rimini is important" [Historical Archive of the Superintendence of the B.A.P. of Ravenna, nW3-1829].

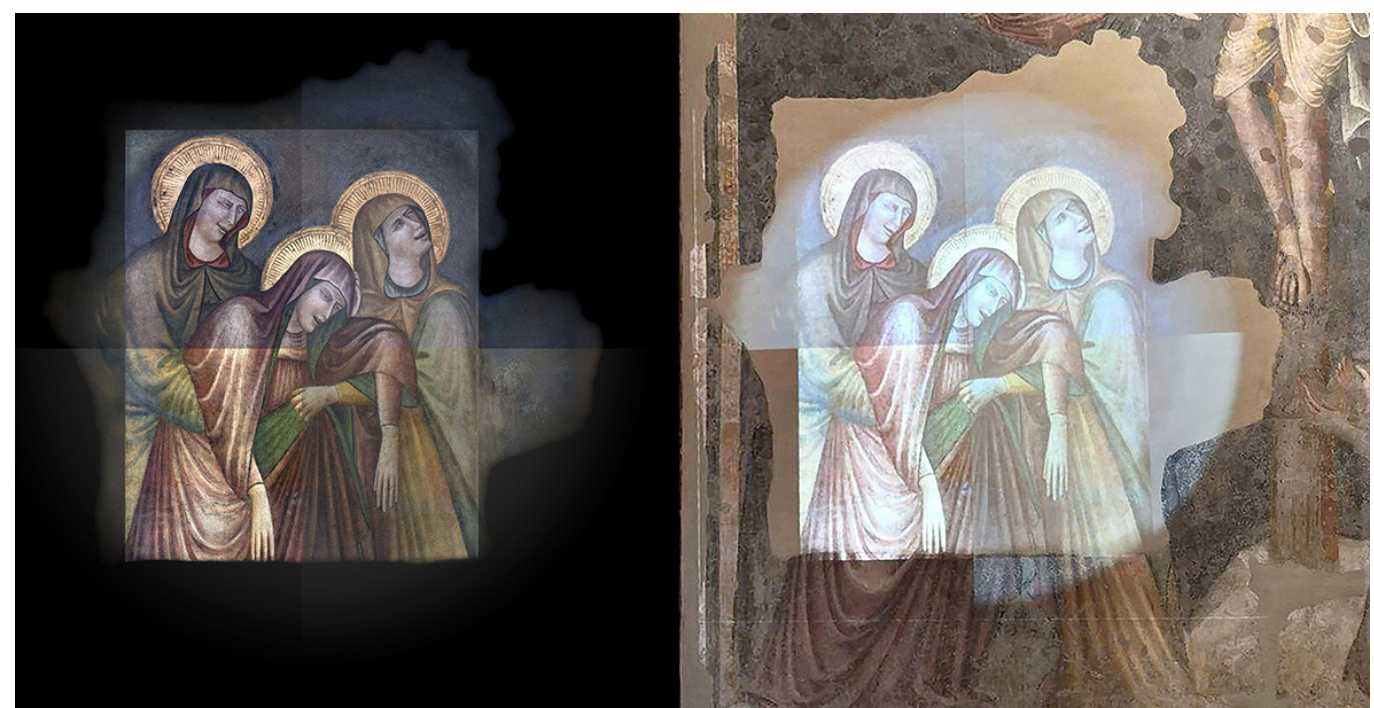


The Napoleonic suppressions (1798), the countless successive changes of ownership and intended use, the war events (1944) and the difficulties of managing the artistic heritage by the Municipal Administration in the post-war period (Bentini 1992) inevitably led to the dispersion of the torn fragments and, consequently, to the loss of the overall view.

In figures 3-7, a first recompositive hypothesis of the entire east wall of the church is proposed, created through the information contained in the consulted graphic and photographic documents. These documents include the surveys made for the municipal report of 1868 [Municipal Historical Archive of Ferrara, 19th century, Public Education, envelope 76 , file $n^{\circ}$ I] and those made in 1918 by the Ferrariae Decus [Mattaliano 1991]. The photographic documentation, kept in the photographic library of Palazzo Bonacossi (Ferrara), the photographic archive of the Polo Museale dell'Emilia Romagna (Bologna) and the Zeri Collection (Bologna), include various images that can be connected to more than 25 different subjects. They allow us to deduce the shape of the detached fragments, as well as the subsequent partitions evidently decided for display reasons (fig. 8). (M.I.).

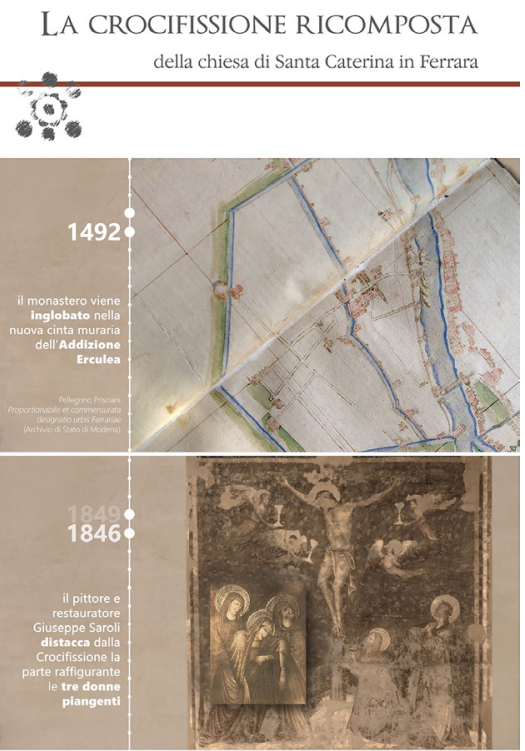

\section{Colour analysis and light projection}

The Crucifixion fresco was recreated by projecting the detached portion depicting the three women, held in Florence, onto the gap in the fresco preserved at Casa Romei in Ferrara. As mentioned above, the selection of the tools and methods used for the mapping was based on the experience gained during the Sogno o son Deste project [Giannetti et al. 2019]. However, a specific workflow had to be devised for this particular case study.

Two types of issue were encountered:

Specific issues.

I) The subject of the projection was not a scholarly reconstruction, but the image of an existing fresco.

2) The colour of the background of the projection (i.e. the colour of the plaster in the gap in the Crucifixion fresco) was not neutral, and affected the colour of the projection to a significant degree.

3) Analysing the colours and simulating the final effect. General issues.

4) As observed in the previous case studies, accurate colour management is not possible when creating the projection slide [Giannetti et al. 2019] and the temperature of the projector lamp affects the final hue. 
The first issue tackled regarded the completion of the fresco. This was entirely carried out using photographs. In detail, images were obtained both of the Crucifixion fresco and of the fragment held in Florence. Since the two objects were restored following very different approaches and are stored in different locations with differently lit surroundings, a colour profiling process was required to compare the two.This was carried out using X-Rite ColorChecker. First, a high-resolution photographic campaign of the frescoes depicting the 'three women' was conducted (fig. 9).

Next, photographs were taken of the Crucifixion preserved in Ferrara. In this case, since the fresco was not the subject of the projection, but simply the backdrop, it was not deemed necessary to use the material from the high-resolution campaign (fig. I); instead it was sufficient to take a photograph of the gap (profiled using Color Checker and created using the same camera and lens as the fragment from Florence), so that a comparison of the colour of the painted sections near the gap could be made and the background colour of the projection could be acquired (the plaster in the gap has a beige hue).

Once the images had been corrected, using the colour profile extracted using Color Checker, the colours of the two frescoes could be compared, and the colour balance of the portion to be projected was altered so the colours were identical in the final result.To do this, the colour had to be corrected while simultaneously simulating the effects of the projection, in particular the blending of the colours through subtractive colour mixing: black, therefore, can only be obtained through the "non-projection" of light in a completely dark environment. For the simulation it was decided to use the blending modes in Photoshop, and in particular the Screen and Hard Light modes.

Aside from the simulation, it must also be remembered that the overall lighting of the environment also affects the overall perception of colour, and if this lighting comes from outside, it will vary over time. In its current location, the Casa Romei Crucifixion is lit by several windows on the right-hand side and a door on the left-hand side.

As described in the previous studies, GOLED analogue projectors were once again chosen for this mapping project. When dealing with the colour of the projection, these add the variables caused by the 'laser ablation' of the slides and the temperature of the LED lamp (nominally 4000K); the actual colour result could therefore only be checked afterwards, by projecting a few test slides. During the test projection, other photographs were taken for comparison with the original digital file of the test slide. (S.G.).

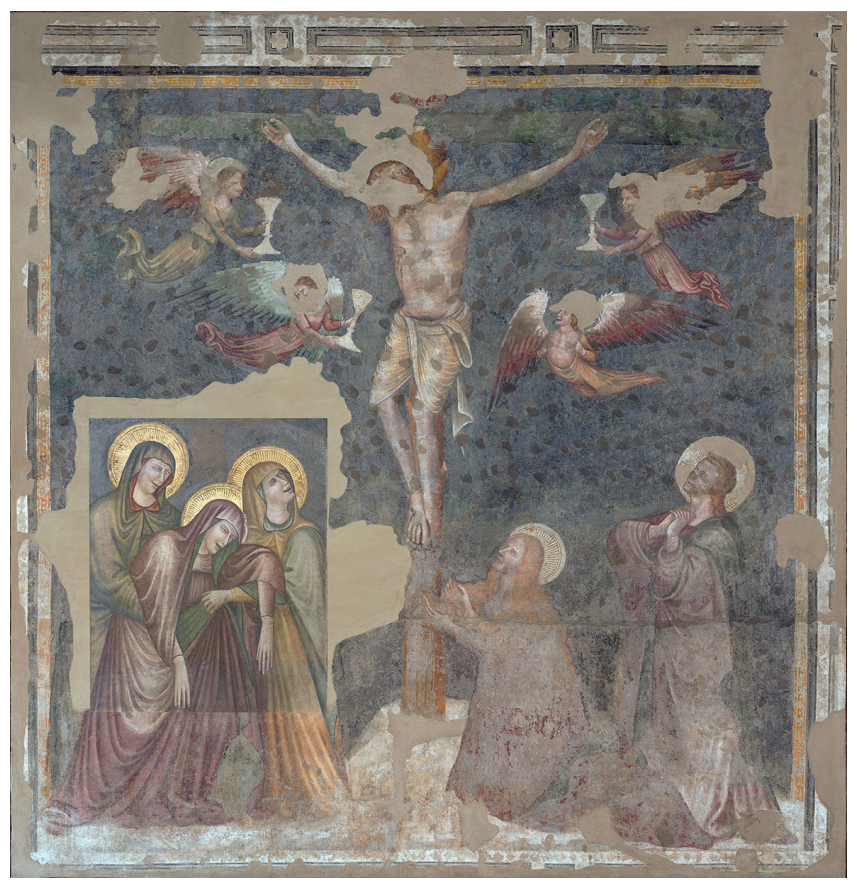




\section{Conclusions}

Through the described workflow, now similar to a light-design project, it was possible to recompose a pictorial work of art to show it in its entirety as in the previous case studies. This purpose has been pursued through the refinement of data acquisition techniques, processing and projection. Finally, the fruition of the cultural heritage was enhanced with the creation of a 5.30 minutes video (fig. I I), explaining the history of the crucifixion, from the foundation of the church that hosted it to the recomposition project here presented (fig. I2). (M.I., S.G.).

\section{Notes}

[I] This part of the project was carried out thanks to the support of BPER bank.

[2] The campaign was conducted using a Canon I00D camera with Canon 70-200 mm f4 (series L) lens, set to $200 \mathrm{~mm}$. 86 photos were required to cover the entire surface of the fresco (with actual dimensions of $130 \times 104 \mathrm{~cm}$ ), taken by rotating the camera around the nodal point of the lens using a motorised head, with a $20 \%$ overlap. The images were then stitched using Kolor Autopano Giga software; the final image had dimensions of $21091 \times 25342$ pixels, equivalent to $214 \times 178 \mathrm{~cm}$ at 300 dpi (i.e. greater than I:I scale).

[3] The Screen mode is defined by Adobe as follows: "Looks at each channel's colour information and multiplies the inverse of the blend and base colours. The result colour is always a lighter colour. Screening with black leaves the colour unchanged. Screening with white produces white. The effect is similar to projecting multiple photographic slides on top of each other". The Hard Light mode is defined by Adobe as follows: "Multiplies or screens the colours, depending on the blend colour. The effect is similar to shining a harsh spotlight on the image. If the blend colour (light source) is lighter than $50 \%$ grey, the image is lightened, as if it were screened. This is useful for adding highlights to an image. If the blend colour is darker than $50 \%$ grey, the image is darkened, as if it were multiplied. This is useful for adding shadows to an image. Painting with pure black or white results in pure black or white".

\section{References}

Bentini Jadranka (1992). Pinacoteca Nazionale di Ferrara. Catalogo generale. Introduzione di Andrea Emiliani - Consulenza scientifica di Federico Zeri. Bologna: Nuova Alfa.

Brandi Cesare (1935). Mostra della pittura riminese del Trecento: Rimini, 20 giugno-30 settembre 1935. Rimini:Tip. Garattoni.

Giannetti Stefano, Lodovisi Achille, Sardo Andrea, Grassivaro Marco, Incerti Manuela (2019). Esperienze di projection mapping per la valorizzazione delle facciate dipinte nei territori estensi. Experiences in projection mapping. Enhancing the painted facades of the Estes. In Paolo Belardi (a cura di). Riflessioni: l'arte del disegno/il disegno dell'arte/Reflections: the art of drawing/the drawing of art. Atti del $39^{\circ}$ Convegno dei Docenti delle Discipline della Rappresentazione. Perugia 19-21 settembre 2019, pp. |62| - 628. Roma: Gangemi.

Lamborghini Giovanni, (2008). Il tassello mancante nella Crocifissione di Santa Caterina Martire. In Voci di una città, 28, pp. I 5- I7.

Mattaliano Emanuele (199|). Un affresco restaurato dalla ex chiesa di s. Caterina martire. In Ferrariae Decus, pp. I - I3.

Varese Ranieri (1976). Trecento ferrarese. Ferrara: Cassa di Risparmio di Ferrara.

\section{Website}

<https://helpx.adobe.com/it/photoshop/using/blending-modes.html> Adobe. Guida Utente Photoshop, Metodi di Fusione.

$<$ https://www.sognoosondeste.it/>.

\section{Authors}

Manuela Incerti, Università di Ferrara icm@unife.it

Stefano Giannetti, Università di Ferrara, stefano.giannetti@unife.it

Achille Lodovisi, Fondazione Rocca di Vignola, centrodidocumentazione@fondazionedivignola.it

Andrea Sardo, Direttore Museo di Casa Romei, Ferrara, andreaquintino.sardo@beniculturali.it

Per citare questo capitolo: Incerti Manuela, Giannetti Stefano, Lodovisi Achille, Sardo Andrea (2020). Dal rilievo al projection mapping. La ricomposizione degli affreschi della chiesa di Santa Caterina Martire in Ferrara/From the Survey to Projection Mapping. The Recomposition of the Frescoes of the Church of Santa Caterina Martire in Ferrara. In Arena A., Arena M., Brandolino R.G., Colistra D., Ginex G., Mediati D., Nucifora S., Raffa P. (a cura di). Connettere. Un disegno per annodare e tessere. Atti del $42^{\circ}$ Convegno Internazionale dei Docenti delle Discipline della Rappresentazione/Connecting. Drawing for weaving relationships. Proceedings of the 42th International Conference of Representation Disciplines Teachers. Milano: FrancoAngeli, pp. 3365-3382 